\title{
Leyenda negra y leyenda azul: la visión de Felipe II y el Infante don Carlos en el teatro español del siglo $\mathrm{XX}$
}

\author{
Marta Olivas FuenTES \\ Universidad Complutense de Madrid ${ }^{1}$ \\ molivas@filol.ucm.es
}

MAX.- ¿Pues qué temes?

EL PRESO.- Que se diviertan dándome tormento.

MAX.- ¡Bárbaros!

EL PRESO.- Hay que conocerlos.

MAX.- Canallas. ¡Y ésos son los que protestan de la leyenda negra!

Escena VI, Luces de Bohemia, Ramón del Valle-Inclán

\begin{abstract}
RESUMEN
El presente artículo analiza el tratamiento de la llamada "leyenda negra" y más, en concreto, del enfrentamiento entre Felipe II y su hijo, don Carlos, a través de dos dramas paradigmáticos en este sentido: Felipe II. Las soledades del rey, de José María Pemán y Tragicomedia del serenísimo príncipe don Carlos, de Carlos Muñiz. Mediante el cotejo de ambas, se evidencia el uso ideológico de la Historia no sólo con fines teatrales sino esencialmente políticos. El estudio se completa con una revisión de Don Carlos, de Salvador de Madariaga y la versión de Calisto Bieito y Marc Rosich de la obra de Schiller Don Carlos, príncipe de España.
\end{abstract}

Palabras clave: leyenda negra, teatro español del siglo XX, José María Pemán, Carlos Muñiz.

\section{ABSTRACT}

This article analyses the treatment of the "black legend" and, more specifically, the conflict between Felipe II and his son, don Carlos, through two paradigmatic plays in this sense: Felipe II. Las soledades del rey, by José María Pemán and Tragicomedia del serenísimo príncipe don Carlos, by Carlos Muñiz. Thanks to the comparison between them, we are able to demonstrate the ideological use of History not only with theatrical aims but also, and essentially, with political aims. The study is completed with a review of Don Carlos, by

\footnotetext{
${ }^{1}$ Beneficiaria del programa de ayudas para la Formación del Profesorado Universitario que otorga el Ministerio de Educación.
} 
Salvador de Madariaga and the version of Calisto Bieito y Marc Rosich of Schiller's Don Carlos, príncipe de España.

Keywords: black legend, Spanish theatre of $\mathrm{xx}^{\text {th }}$ Century, José María Pemán, Carlos Muñiz.

La leyenda negra ha sido uno de los temas más traídos y llevados por los historiadores desde el siglo XVI. Como es bien sabido, este marbete apela a la imagen negativa de España que empezó a gestarse a finales del Quinientos a partir de fuentes como Brevísima relación de la destrucción de las Indias, de Bartolomé de las Casas (1552); El libro de los mártires, de John Foxe (1554); Exposición de algunas mañas de la Santa Inquisición española, de Reinaldo González Montano (1567); Apología de Guillermo de Orange (1581) o Relaciones, de Antonio Pérez (1598). Esta propaganda antiespañolista fue fomentada durante el Siglo de Oro especialmente por los ingleses, debido al ingente poder de la Monarquía Hispánica que, por aquel entonces, representaba su principal competidor comercial. Así definía el término Julián Juderías en 1914²:

Por "leyenda negra" entendemos el ambiente creado por los fantásticos relatos que acerca de nuestra Patria han visto la luz pública en casi todos los países; las descripciones grotescas que se han hecho siempre del carácter de los españoles como individuos y como colectividad; la negación, o por lo menos, la ignorancia sistemática de cuanto nos es favorable y honroso en las diversas manifestaciones de la cultura y del arte; las acusaciones que en todo tiempo se han lanzado contra España, fundándose para ello en hechos exagerados, mal interpretados o falsos en su totalidad... En una palabra, entendemos por leyenda negra, la leyenda de la España inquisitorial, ignorante, fanática, incapaz de figurar entre los pueblos cultos, lo mismo ahora que antes, dispuesta siempre a las represiones violentas; enemiga del progreso y de las innovaciones; en otros términos, la leyenda que, habiéndose empezado a difundir en el siglo XVI, a raíz de la Reforma, no ha dejado de utilizarse en contra nuestra desde entonces, y más especialmente en momentos críticos de nuestra vida nacional. ${ }^{3}$

\footnotetext{
${ }^{2}$ Precisamente y, según estudiosos como Luis Español Bouché o Jesús Villanueva, el término "leyenda negra" en castellano fue acuñado por la escritora Emilia Pardo Bazán en 1899 con motivo de unas ponencias en París sobre las consecuencias del Desastre del 98. Asimismo, el 14 de julio de 1909, Vicente Blasco Ibáñez pronunció una conferencia titulada "La leyenda negra de España" en el teatro Odeón de Buenos Aires dentro del ciclo de ponencias que llevó a cabo en la capital rioplatense [L. Español (2007) p. 107]. Sin embargo y, a pesar de estos precedentes, fue el ensayo La leyenda negra, de Juderías -aparecido en 1914- el que acabaría popularizando el término.

${ }^{3}$ J. Juderías (2003), p. 24.
} 
Como apuntaba Juderías, la leyenda negra no fue un fenómeno que se expandiese exclusivamente durante los Siglos de Oro, sino que fue actualizada en la Ilustración gracias a escritores franceses como Fénelon o Lucien Fébvre, así como se ha empleado en episodios mucho más recientes de nuestra historia, como la Guerra de Cuba. Entonces, la prensa norteamericana también apeló a ella para ganarse a la opinión pública internacional tanto en la polémica acerca del hundimiento del Maine como para presentar a los cubanos a la manera de auténticos mártires sometidos a la tiranía de un pueblo despótico e ignorante. Es precisamente a raíz de estos acontecimientos cuando los regeneracionistas comienzan a escribir sobre ella e introducen el tópico en el siglo XX para intentar explicar el período de decadencia por el cual atravesaba España. Sin embargo, más que por enemigos del país o sectores críticos con los gobiernos de turno, este lugar común fue alimentado de forma constante dentro de las fronteras del país en dos momentos definitorios: en primer lugar, durante la dictadura de Miguel Primo de Rivera y, más tarde, en los primeros años del franquismo. Ambos regímenes lo emplearon como justificación a las críticas de las potencias europeas adoptando una actitud que podría tildarse, cuanto menos, de victimista. Con ello, no sólo conseguían desacreditar cualquier reprobación que procediese del extranjero sino también unir a la nación frente al vituperio externo y la "amenaza" que representaba todo lo foráneo.

En respuesta a esa leyenda negra, el régimen de Franco empezó a generar lo que podríamos llamar "leyenda azul". Esto es, la utilización de los símbolos, personajes y ciertos episodios del pasado como paradigmas para la génesis de una historiografía profundamente ideologizada - en la que sus protagonistas son retratados sin mácula ni se permite concesión alguna a teorías contrarias-. Es a ese pasado glorioso al que el franquismo pretendía adscribirse, señalándose a sí mismo -y, como es obvio, al Generalísimo- como "continuador" de la labor de engrandecimiento de la patria, de una suerte de "misión imperial" enraizada en el Medievo, el Renacimiento y el Siglo de Oro -especialmente del siglo XVI- que encarnaron personalidades muy concretas: don Pelayo, el Cid Campeador, los Reyes Católicos, Carlos I y Felipe II y cuyas principales divisas eran el concepto de Hispanidad y la religión católica.

Partiendo de esta idea y estos objetivos, Felipe II fue considerado por la mitología de la Dictadura la principal atalaya del catolicismo, al tiempo que la Monarquía Hispánica se convertía en la hegemonía a imitar. Por ejemplo, Martín Almagro declaraba en 1943 que España debía volver a ser un «pueblo esencial y creador en el mundo, cuando representamos y servimos a un orden ecuménico católico y monárquico del cual Felipe II será el cénit más esplendoroso» ${ }^{5}$. Para poder presentarlo como tal, se imponía la necesidad de limpiar la imagen tradicional difundida por la

${ }^{4}$ De acuerdo con Carmen Iglesias: «Desde el franquismo se veía toda la historia pasada, salvando a los Reyes Católicos y -sólo en parte- a Felipe II, como una sucesión aberrante de épocas disparatadas» [C. Iglesias (2008), p. 21].

${ }^{5}$ J. Villanueva (2011), p. 126. 
leyenda negra de crueldad, fanatismo y sanguinolencia. Es el fenómeno que Jesús Villanueva denomina «felipismo» ${ }^{6}$.

Las obras del pasado siglo que hemos escogido para ilustrar la presencia de las leyendas negra y azul en el ámbito teatral giran, precisamente, en torno a Su Católica Majestad y, en concreto, a su enfrentamiento con su hijo, el Infante don Carlos. La relación entre ambos fue muy complicada ${ }^{7}$. Don Carlos sufrió siempre de un delicado estado de salud e intentó en varias ocasiones huir del reino ${ }^{8}$. Tras algunas tentativas, intentó llevar a cabo su fuga con la ayuda de su tío, don Juan de Austria, a quien solicitó que lo trasladase a Italia durante una reunión mantenida el 16 o el 17 de enero de 1568. No obstante, éste informó rápidamente al Rey de los planes del heredero, lo que desencadenó la ira del joven Carlos, que intentó acabar con la vida del héroe naval ${ }^{9}$. Fue entonces, cuando Felipe II mandó encerrar al Infante en sus aposentos sin comunicación con el exterior, el 18 de enero. Finalmente, éste moriría el 28 de julio de 1568. Personalidades como Guillermo de Orange en su Apología levantaron suspicacias con respecto a los motivos de su encierro y su muerte, acusando al Rey de haberlo envenenado. La discreción mantenida por Felipe II con respecto a los auténticos motivos de la encarcelación del Infante, que muchos historiadores consideraron un, en palabras de Elías Tormo, «total y absoluto y heroico silencio por salvar el buen nombre de su hijo» ${ }^{10}$ dieron pábulo a estas especulaciones y avivaron la gestación de la leyenda negra.

La primera incursión en el ámbito literario de este episodio llegó de la mano de la novela histórica Histoire de don Carlos, de César Vichard de Saint-Real (1672) y, más tarde, la pieza teatral Don Carlos, Prince of Spain, de Thomas Otway (1676). Estas dos obras -especialmente la novela de Saint-Réal- constituirían el germen del celebérrimo poema dramático de Friedrich von Schiller estrenado en

\footnotetext{
${ }_{7}^{6}$ J. Villanueva (2011), p. 132.

${ }^{7}$ Desgraciadamente, dadas las limitaciones requeridas por un trabajo de estas características no podemos detenernos por extenso en nociones históricas. Para saber más sobre los hechos que tratamos y la evolución de los estudios sobre Felipe II véanse G. Parker (2010) p. 396438 o M. Fernández Álvarez (2006) pp. 395-425. Sobre la visión diacrónica del concepto "leyenda negra", véanse J. Juderías (2003) o J. Villanueva (2011).

${ }^{8}$ Pese a que se creyó que don Carlos pudo haber sido retenido contra su voluntad a causa de un supuesto complot con Egmont y Montigny, los cabecillas de las rebeliones flamencas, para huir a Bruselas y proclamarse gobernador de los Países Bajos, G. Parker destaca que «las evidencias disponibles sugieren que don Carlos tenía la intención de huir a Viena [...] y para ello no necesitaba la ayuda de [...] ningún flamenco» (2010), p. 431.

${ }^{9}$ Véase G. Parker (2010), p. 426.

${ }^{10}$ E. Tormo (1943), p. 198. No obstante, Tormo, jurista e historiador, corroboró la hipótesis del asesinato en sus charlas académicas aunque, en puridad, no existe documento alguno que la justifique.
} 
1787 Don Karlos, Infant von Spanien -Don Carlos, Infante de España- ${ }^{11}$. Casi un siglo más tarde, en 1867, se estrenaría Don Carlo, la ópera de Verdi basada a su vez en el drama schilleriano del Sturm und Drang ${ }^{12}$. Estas dos últimas serán, sin duda, las manifestaciones artísticas por antonomasia a que dio lugar esta historia ${ }^{13}$. Dentro del caso español, las piezas inspiradas en don Carlos o Felipe II se sucedieron sobre todo en el siglo XX debido a ese interés por la leyenda negra que introdujo el movimiento regeneracionista. Como es obvio, la denostación o ensalzamiento de la figura del monarca es inversamente proporcional al vilipendio o elogio de su primogénito y dependerá de la ideología a la que se adscriba su autor.

Felipe II. Las soledades del rey, de José María Pemán, publicada en 1958, es el ejemplo de una obra concebida por y para generar esa leyenda azul. El dramaturgo gaditano, monárquico convencido, ya había escrito durante la República diversas piezas que remarcaban su rechazo al republicanismo y afirmaban una serie de valores pro-monarquía a través de varios personajes. Destacan Cisneros (1934) y, sobre todo, El divino impaciente (1933). Esta última versa sobre la vida de San Francisco Javier en la que, citando a Emilio Peral, «la figura del mítico misionero constituye un punto de partida para desarrollar una defensa del rey -en este caso de Portugalcomo garante de justicia y elemento imprescindible para desequilibrar la balanza a favor del interés divino frente al terrenal» ${ }^{14}$. Asimismo, Pemán fue el autor de Historia de España contada con sencillez, que rebatía la leyenda negra sobre Felipe II. Según él, la historia de España era una sucesión de "cruzadas" desde la Reconquista hasta el Alzamiento de Franco en 1936. Sin ir más lejos, algunos teóricos afectos al régimen del Generalísimo tendían puentes entre el "Centinela de Occidente" y el heredero de Carlos I. Al ensayista González Fernández de la Mora se le ha atribuido la frase: «Franco es el hombre más importante que ha tenido España, por lo menos, desde tiempos de Felipe II».

${ }^{11}$ A este mismo período pertenece el drama Filippo II, del literato italiano Vittorio Alfieri, escrita en 1781 y publicada en 1783. Otro autor de transición -esta vez entre el Romanticismo y el Realismo-, el español Gaspar Núñez de Arce, dedicó también la primera de sus obras teatrales a la figura de Su Católica Majestad en El haz de leña (1872). Ya en los últimos años, Ramón Gil Novales, llevó a las tablas la crisis de estado consecuencia de la caída en desgracia del secretario real, Antonio Pérez, en La noche del veneno (1989).

${ }^{12}$ Estas obras bebían de las mismas fuentes indirectas, lo cual ayudó a extender una determinada versión de los hechos, concretamente, la más cercana a la Apología de Orange (a este respecto, véase nota 11). Además de estas obras, muchos pintores y compositores fueron atraídos por el mundo y la época de Felipe II. Véase como ejemplo el Egmont, de Goethe (1788) que musicó Beethoven.

${ }^{13}$ Schiller presentó al Infante como un hombre sensible y rebelde, enamorado de Isabel de Valois, la que había sido su prometida y convertida ahora en su madrastra, al ser la tercera esposa del Rey. Como telón de fondo aparece la insurrección de los Países Bajos contra España, en la cual resulta de capital importancia el personaje del Marqués de Poza.

${ }^{14}$ E. Peral (2006), p. 356. 
En Felipe II, José María Pemán presenta a un rey tremendamente alejado de la imagen que la leyenda negra se empeñaba en difundir. El monarca es retratado, haciendo honor a su fama, como un hombre prudente ${ }^{15}$, que soporta el peso de un gobierno complicado y las múltiples amenazas que lo acechan: la Reforma, la guerra en Flandes, el espionaje de franceses e ingleses o la traición de Antonio Pérez y su hijo Carlos. Por el contrario, las faltas que le acarreaban las monarquías extranjeras son las que "adornan" a su vástago. Lejos de sufrir discapacidad alguna -en acotación se especifica «No ha de parecer bobo ni idiota. Más bien loco y voluntarioso»-, don Carlos queda inmortalizado como un joven caprichoso, arrebatado y consumido por la ambición y los celos del ilimitado poder de su padre y, sobre todo, de su amor con Isabel de Valois ${ }^{16}$. Muchas son las referencias a lo largo del drama que pretenden refrendar esta imagen de intransigencia y tiranía del Infante: las amenazas de muerte y el maltrato a varios miembros de la corte por motivos absurdos o el manifiesto odio visceral hacia su padre del que da buena cuenta esta intervención extraída de un diálogo con el prior del convento de Atocha:

DON CARLOS.- Lejos de ello [de perdonarlo] le odio más cada día... ¡Y me propongo matarlo!... No piense vuestra reverencia que dé un paso atrás... Cuando se ha tomado ese camino, no hay que volver y dudar... Porque el enemigo que odio... ¡ ies el Rey mi padre!

[...] Sí... ¡Le odio!... Sabedlo bajo secreto de confesión... Compartid conmigo este secreto... Sufrid conmigo esta llaga... escondida... que nos mancha la ropa

\footnotetext{
${ }^{15}$ De hecho, uno de sus apelativos más recurrentes fue, precisamente, "El Prudente", así lo constató Antonio de Herrera y Tordesillas en su Historia General del Mundo del tiempo del Señor Rey don Felipe II, el Prudente, escrita hacia 1590.

${ }^{16}$ La supuesta relación incestuosa entre el Infante don Carlos e Isabel de Valois, constituyó uno de los episodios más subrayados por los defensores de la leyenda negra. Tal y como apunta Geoffrey Parker, el tratado Diógenes, aparecido en los Países Bajos en 1581 «planteaba una acusación que se mantendría vigente durante mucho tiempo: que don Carlos se había enamorado de su madre, Isabel de Valois, y que Felipe les había asesinado a los dos al enterarse de ello» [G. Parker (2010), p. 397]. Este testimonio caló hondo tanto en la historiografía posterior -History of the reign of Philip II, de Robert Watson (1777)- como en la versión de los hechos que se ofrecían las literaturizaciones del conflicto entre el Infante y su padre a las que nos hemos referido. Asimismo, en las Relaciones de Antonio Pérez (1598), quien fuera secretario real acusaba al monarca de ser el responsable no sólo de la muerte del Infante sino también de la propia reina. Parker asegura que «los documentos que han llegado hasta nosotros contienen pruebas de una estrecha relación con la reina Isabel» si bien «parece altamente improbable que cualquier conducta inapropiada pudiera haber tenido lugar en un palacio donde cada uno de los miembros de la familia real esta permanentemente rodeado de cortesanos [...]. No existe ninguna prueba de que el príncipe y su madrastra pasaran tiempo juntos» G. Parker (2010), p. 431-432.
} 
por dentro... de humores pestilentes... y no se ve ni se dice... ¡Si no podéis absolverme!... ¡Pero me daréis una Hostia sin consagrar! ${ }^{17}$

Don Carlos detesta la burocracia y el modo sibilino de conducirse del Rey ${ }^{18}$. Pemán sube a las tablas un joven que sueña con "mancharse las manos" y ser un gran soldado, como su abuelo. Sin embargo, cualquiera de sus virtudes -y en la obra no se nos muestra ninguna- es desacreditada por un airado despotismo y engreimiento que, unido a su carácter impetuoso, resulta no sólo peligroso, sino mortal ${ }^{19}$. Por ello, la decisión de Felipe II de retenerlo, es justificada no sólo como política de estado sino prácticamente como un designio divino. De hecho, el Rey Católico, como quedará demostrado a lo largo de la obra, supedita a Dios todas las acciones que emprende -ya en el ejercicio de su cargo, ya en el ámbito personal-: «Entender no es el oficio de la fe... ni el del amor», declara [ib.: 89]. Así pues, el que fue considerado el hombre más poderoso del mundo se tenía a sí mismo por una herramienta de la voluntad de Dios:

PRIOR.- Os tacharon de riguroso. Decían que el padre del Evangelio perdonó al hijo pródigo.

REY.- ¡Él pudo permitirse ese lujo!... Dios deja hacer, regala libertad. Él se reserva la misericordia, la parte brillante. ¡Pero a mí me ha encargado la administración de los negocios de la tierra!... ¡Sucias cuentas éstas!... Él es el Buen Pastor: ¡bello oficio de prados y de estrellas! Pero todo buen pastor necesita un perro... ¡ a veces un perro flaco y sarnoso! ¡Yo he sido el perro del buen pastor!... ¡Y los que se gozan y se recrean porque el ganado esté ahí, a pesar de todas las tormentas y pedriscos, apiñado, sin dispersión ni pérdida..., le dan con el pie al pasar-iquítate, no estorbes!- al perro que lo guardó lo mejor que supo ${ }^{20}$.

Más elocuente resulta aún la siguiente intervención.

REY.- ¡Mi pueblo!... ¡Cuánto me costáis, mis hijos! Tenga por cierto, reverencia, que mi determinación es tan justa y tan necesaria y conforme al servicio de Dios

${ }^{17}$ J. M. Pemán (1958), p. 73.

${ }^{18}$ En diálogo con su padre, declara:

DON CARLOS.- Odio esa sucia prudencia, ese paso lento que no suena sobre las alfombras..., como el de los gatos en el Alcázar... Todo lo queréis a media voz. [J. M. Pemán (1958), p. 77]

${ }^{19}$ Como ejemplo de la constante "contraargumentación" ejercida contra don Carlos, véase este extracto de la conversación entre Isabel de Valois y Felipe II cuando éste le comunica que ha confinado a su hijo:

REINA.- Conmigo era agradable y dócil...

REY.- También con la ambición lo era; también por los malos consejos...; ¡también acabaría siéndolo con la herejía! [J. M. Pemán (1958), p. 90]

20 J.M. Pemán (1958), p. 67. 
y al bien público como está en mi corazón... (Baja y avanza lentamente. En silencio. Se para de vez en cuando.) Habrá que dar cuenta a las Cortes de Europa del suceso... (Pausa). [...] Afirmaréis que hubo causa muy justa y no entraréis en más razones... [...] Don Luis... Dispondréis criados de confianza que se mezclen por los mercados con los correos del pueblo y digan cómo esto no es prisión, sino guarda y reclusión de la persona del Príncipe... (Pausa. Con gran emoción.) Estas razones se darán de este hecho tan doloroso... Porque esta mañana se ha dicho en Madrid, salvadas las distancias de infinitas, como una terrible misa humana: la que cabe en la pequeñez de un mortal... He hecho a Dios un sacrificio de mi carne y de mi sangre... ${ }^{21}$

Muy inteligentemente, el escritor gaditano explica el oscurantismo alrededor de la muerte de don Carlos que dio lugar a las murmuraciones y la teoría del filicidio que difundió la leyenda negra al que nos referíamos anteriormente. El afán del Rey por "proteger" el buen nombre de su hijo es precisamente lo que despertará recelos en buena parte de la opinión pública. Más adelante, cuando el Infante está a punto de morir y Felipe II se dispone a «darle una su última bendición $»^{22}$, será el padre Chaves quien le pedirá que no se acerque a los aposentos de su hijo para evitar alterarlo. En otras palabras: es la bonhomía del Rey la que genera, injustamente, su infamia.

Tal era la resignación y la confianza de Felipe II en la voluntad de Dios que, al final del primer acto, cuando se le comunica la victoria en Lepanto contra el Turco, él la considera una suerte de recompensa divina por el sacrificio de su hijo: «Dios es un buen pagador... Siempre esperé el precio largo de aquello que me quitó... De aquellos besos que se me quedaron secos en los labios... ¡Nunca sabrá el mundo que el Príncipe don Carlos, mi hijo, murió en la victoria de Lepanto!... (Transición. Serenidad). Te Deum, padre Prior,... ¡Te Deum!»" ${ }^{23}$. Esta "subida a los altares del Monarca" enlaza a la perfección con las ideas esgrimidas sobre la monarquía y la figura del Rey en El divino impaciente, a las que hemos aludido.

La imagen de nobleza y honestidad de Felipe II que se nos ofrece en el drama se aviva en aras de una "beatificación" del personaje, reforzada por las analogías de tipo religioso - tan hiperbólicas que harían sonreírse a la mayoría de los espectadores del XXI- de que está trufado el texto. Estos son guiños a la figura del monarca como gran valedor del catolicismo frente a la amenaza calvinista. La recuperación de este valor simbólico del personaje resultaba esencial en la época - cuando comenzaban a avistarse tímidamente los inicios del aperturismo y el abandono de la autarquía en la dictadura franquista- para enfervorecer la creencia de los españoles frente a otra amenaza: la del comunismo y la masonería a la que la propaganda del Régimen aludía un día sí y otro también. A este respecto, el Infante don Carlos se

\footnotetext{
${ }^{21}$ ib., p. 87-88.

22 ib., p. 96.

${ }^{23}$ ib., p. 107.
} 
alzaba, una vez más, como contraejemplo, pues representaba precisamente esa amenaza al catolicismo al ser retratado por Pemán como sospechoso de hugonote.

El segundo acto de la obra se ocupa de otro de los episodios más apasionantes de la vida de Su Majestad Católica y que también contribuyó al engrandecimiento del antihispanismo: la muerte de Juan de Escobedo y la consiguiente huida del secretario real, Antonio Pérez, primero a Aragón y más tarde a Inglaterra. Como no podía ser de otra manera, Pérez, un traidor sin escrúpulos, es señalado como el único responsable del asesinato del hombre de confianza de Juan de Austria, exculpando en todo momento a Felipe II. El momento aglutinador de toda la pieza es el del cortejo fúnebre del monarca. En él asistimos a los llantos de un coro compuesto por todos los estamentos y sectores de la sociedad de la época a modo de réplica definitiva a la leyenda negra y a sus voceros.

-Ahí va la prudencia..., con paso silencioso en busca de paz...

[...]

-Se le pudrieron en las soledades del alma las palabras que no podía decir..., como los ratones en los desvanes del Alcázar.

- ¡Y ahora empezad vuestra farsa... Los bufones del mundo!

-Callado le tenéis ya, rendido de responsabilidades y pensamientos solitarios...

-Calumniadle... ¡Ya le tenéis maniatado por la muerte!... ¡Aprovechaos: ya es vuestro!

$[\ldots]$

-Perdonados te son tus pecados... porque nos has amado mucho. ${ }^{24}$

En respuesta a esta leyenda azul, surge dentro del discurso antifranquista una afirmación de la leyenda negra como realidad histórica de la que la dictadura constituía el último eslabón ${ }^{25}$. Algunas de las manifestaciones más señeras las constituyen la Carta al general Franco de Fernando Arrabal, publicada en 1971 y la pieza que hemos escogido para ilustrar este período: Tragicomedia del serenísimo príncipe Don Carlos, del dramaturgo madrileño Carlos Muñiz, escrita un año más tarde. Como era presumible, la obra sufrió innumerables encontronazos con la censura. La encarnación de la libertad del individuo en don Carlos y la aniquilación de éste a manos de un Felipe II que, lejos de constituir ese dechado de virtudes nacionales

${ }^{24} i b .$, p. 202.

${ }^{25}$ Historiadores como Herbert Southworth declaran:

No existe la menor duda posible de que hoy dicha leyenda negra es más negra que nunca. Felipe II fue un santo comparado con Francisco Franco, la Inquisición fue un inocente pasatiempo comparada con las sistemáticas matanzas que llevaron a cabo oficiales y soldados de la cruzada franquista y, finalmente, ni un solo conquistador español trató a los nativos americanos con la crueldad y el odio organizado que el ejército y la Iglesia emplean contra los españoles para redimir a su patria del pecado del imperialismo. [apud J. Villanueva (2011), p. 158]. 
retratado por Pemán, encarnaba la figura de un tirano impío y supersticioso resultaba absolutamente inconcebible para los censores. A pesar de la labor de erudición que Muñiz declaró haber llevado a $\operatorname{cabo}^{26}$ y a su condición de finalista del Premio Lope de Vega de 1972, el Ministerio de Información se opuso no sólo a que el texto fuese premiado sino también a cualquier tipo de representación. Así lo reconocía el propio autor en una entrevista a Ángel Laborda en $A B C$ : «el concejal que representaba al Ayuntamiento de entonces se opuso a que fuese premiada: no estaría de acuerdo con la verdad histórica» ${ }^{27}$. Tragicomedia ... estuvo prohibida hasta la desaparición de la censura, lo que impidió el estreno previsto en el Teatro Poliorama de Barcelona en 1973 y que, finalmente, se llevaría a cabo ya en democracia, en 1980. La obra aborda el tema del «felipismo» pero desde el envés de las lecturas anteriores. Para abordar esa España absolutamente monstruosa -según el autor, un reflejo de aquélla de los sesenta y setenta del siglo pasado-, Muñiz hizo uso de la estética expresionista que ya cultivase en obras anteriores, lo cual supone toda una declaración de intenciones. El dramaturgo construye un rey fanáticamente religioso y obsesionado por el poder -sin ir más lejos, la obra se abre con un prólogo donde asistimos a la recreación del celebérrimo auto de fe en la plaza mayor de Valladolid celebrado en 1559-. Son muchos los momentos de Tragicomedia... en los que el monarca manifiesta su odio por el protestantismo y lleva su afán de purga hasta sus últimas consecuencias. Veamos un ejemplo:

FELIPE II.- Dolido, no. Isabel... Sois demasiado joven y confundís las palabras... Comprended rectamente... estoy dolido por la pasividad de vuestra madre y de sus consejeros ante la incomprensible libertad que gozan en Francia los calvinistas y aun los luteranos... Respecto a los hugonotes, lo único que anhela mi corazón de cristiano es que sean exterminados totalmente.

$[\ldots]$

ISABEL.- (Aturdida.) Os felicito por tanta lealtad a los últimos deseos de vuestro padre. Sois tan buen hijo como esposo. Sin embargo... os ruego que lo comprendáis... No defiendo, ni amo, ni gusto de la herejía, pero pienso que acaso el destino podría hacer un día de este hijo, que golpea mi vientre, un amigo de las ideas heréticas, y al pensarlo...

FELIPE II.- (Contundente.) Jamás, doña Isabel, jamás ocurrirá eso, os lo aseguro. Si ocurriera, no tardaría un instante en entregárselo al verdugo. ${ }^{28}$

\footnotetext{
${ }^{26}$ «Menéndez Pidal, Césare, Jean Cassou, W. Thomas Walsh, fray José de Sigüenza, Pfandl, Amezua, Gachard y otros autorizados investigadores o historiadores como el padre Sigüenza proporcionan las referencias de sucesos que Carlos Muñiz ha enhebrado de la trama dramática de su tragicomedia» afirmaba López Sancho en su crítica al espectáculo [L. López Sancho (1980), p. 53]. La teoría del envenenamiento sostenida por los tratadistas de la leyenda negra (sobre todo Guillermo de Orange) es mantenida por Muñiz.

27 A. Laborda (1980).

${ }^{28}$ C. Muñiz (2005), p. 469.
} 
En este diálogo, Muñiz parece responder al sacrificio atormentado y silencioso que sufre el Rey Católico en la obra de Pemán. Su determinación es firme y no sufre remordimiento ni pesar alguno al llevar sus designios hasta sus últimas consecuencias. Si tuviese que matar a alguno de sus hijos, no dudaría en hacerlo ${ }^{29}$. Como se nos dirá más adelante: el fin siempre justifica los medios. Asimismo, sus intrigas para acabar con la rebelión en Flandes mediante el engaño a sus principales cabecillas -entre ellos el Duque de Montigny al que encarcelará y asesinará- y la encomienda de las tropas a un sanguinario Duque de Alba se llevan a término por iniciativa propia. El Felipe II de Muñiz cumple todos los esquemas de la leyenda negra al encarnar a un hombre mentiroso e infame, capaz de traicionar a todos aquellos que confían en él. Por otro lado, hallamos a un don Carlos físicamente mermado que sueña, no sólo con alcanzar un lugar capital en la Corte -como corresponde a su ascendencia- sino, sobre todo, con el respeto de los que le rodean y la libertad personal para poder llevar a cabo sus decisiones. Uno de sus principales empeños a lo largo de toda la obra es casarse con Ana de Austria en lugar de con su tía doña Juana que, de acuerdo con el texto de Muñiz, habría abusado de él en su infancia. A este motivo achaca el propio príncipe sus dificultades para mantener relaciones sexuales: la causa principal del rechazo de su padre como heredero. Finalmente, don Carlos, en una escena que roza lo esperpéntico, será capaz de yacer -ante notario- con una plebeya gracias a una poción que le facilita el boticario. Sin embargo, todo será inútil a ojos de su padre, siempre entretenido con sus reliquias y sordo a sus requerimientos.

Esta imagen de perversión y endogamia de los Austrias nada tiene que ver con la castidad y recogimiento que adornaban al Rey de la leyenda azul. En la creación de Muñiz, en lugar de aquel cándido enamorado de Isabel de Valois, se nos presenta a un monarca rijoso y mujeriego. De hecho, la obra también aborda de manera transversal el idilio entre la Princesa de Éboli y el rey, otra de las aristas de la leyenda negra. Así lo hace constar don Carlos en un diálogo con Ruy Gómez, Príncipe de Éboli:

DON CARlos.- No son bromas, Ruy Gómez; es la pura verdad. Vuestra esposa es una gran ramera... Mas qué importa, ¿verdad? Si el rey Felipe luce en su frente la corona de España, el Ruy Gómez no ha de ser menos y puesto a lucir, luce los cuernos más airosos y nobles de esta corte. ¿No habéis reparado en que la católica España parece un gran lecho de gatos en celo cada noche? ¿Y que el único que no fornica es el loco, el hereje príncipe don Carlos? (Quita violentamente el

\footnotetext{
${ }^{29}$ Durante el auto de fe en Valladolid se produce una conversación que parece anticipar el final de la obra en una especie de ritornello. Al ver en ardiendo en el patíbulo a don Carlos de Seso, Felipe II declara: «iSi el príncipe, mi hijo, fuera tan malo como don Carlos de Seso, yo mismo arrimaría los palos a su hoguera!» C. Muñiz (2005), p. 448. Efectivamente, la pieza concluye con la muerte de otro Carlos: ese mismo hijo al que alude el Rey.
} 
retrato de las manos de su tío.) Ruy Gómez, ¿dónde se halla mi padre? ¿Está en oración o está acostado con alguna dama? A propósito, Ruy Gómez, ¿vos no tenéis amante? ${ }^{30}$

Si en Felipe II, hablábamos de una "beatificación", o de un retrato maniqueo de la relación entre el Rey y su hijo, en Tragicomedia ... asistimos a un fenómeno similar. Aunque don Carlos es un personaje éticamente más integro, no deja de tener un carácter arrebatado y pulsional. Salvando las distancias, podríamos comparar al Infante del primer acto de la pieza con el Segismundo en la segunda jornada de $L a$ vida es sueño: un hombre azotado por unos terribles y taxativos decretos paternos a quien su falta de templanza le lleva a actuar con desmesura y, a veces, a cometer atrocidades. Por tanto, más que una radical polarización, existe una desigualdad en el diseño de los personajes: la entidad de la figura protagónica hace languidecer al resto de personajes, que casi rozan la tipificación. Así, don Carlos es un carácter complejo mientras que Felipe II resulta, más bien, una exagerada caricatura -valga el pleonasmo-.

Las escenas de corte grotesco -sobre todo relacionadas con la pasión del Felipe II por la taxidermia sacra y el bufón Estebanillo, a veces alter ego del monarcaalternan con algunas de un realismo liminar, casi naturalista. Coincido con la opinión de López Sancho en $A B C$ cuando advertía que Muñiz destruye «toda la schilleriana y retrotrae los hechos a un clima de feroz realismo, de burla desesperada, de expresionismo interior» y añadía: «Hay brutal reflejo de una realidad imaginada, reconstruida, sobre testimonios e interpretaciones históricos» ${ }^{31}$. La interpretación histórica de algunos críticos camina hacia dos claras identificaciones -que también se podían advertir en Pemán aunque, obviamente, con una valoración totalmente distinta-: Felipe $I I=$ Franco, mientras que don Carlos $=$ oposición antifranquista . Así queda expuesto en el siguiente extracto:

D. CARlos.- (Voz ronca. Sombrío.) Señora, jamás el fin justifica los medios, suele decir mi padre. ¿O acaso sería ético, dice el Rey, quitar a los nobles sus tierras para dárselas a los hambrientos vasallos que las trabajan? ¿Consideráis lícito no cortar de raíz la vida del hereje so pretexto de no disponer de la vida de un semejante? ¿Quién osaría justificar que el capitán no atacase al enemigo por temor a poner en peligro la vida de sus soldados? Señora... el fin no justifica los medios... Tampoco en el teatro... Y, sin duda, por eso el cardenal Espinosa, queriendo hacerse aún más grato a mi padre, ha prohibido a Cisneros representar... ${ }^{32}$

Y más tarde, justo antes del encarcelamiento del Infante:

\footnotetext{
${ }^{30}$ ib., p. 476.

${ }^{31}$ L. López Sancho (1980), p. 53.

${ }^{32}$ C. Muñiz (2005), p. 505.
} 
D. CARLOS.- (Hecho un ovillo en el suelo, lanza un alarido.) ¡Matadme, os digo! ¡Matadme! ¡Quiero ser libre! (Golpea las manos contra el suelo mientras grita obsesivamente.) ¡Libre! ¡Libre ! ¡Libre! ¡Libre! (Solloza.) ${ }^{33}$

Evidentemente, la analogía entre el cautiverio de don Carlos y el cautiverio de muchos españoles -ya en prisión, en el exilio o dentro de ellos mismos-, denota el destinatario de los reproches del príncipe: el régimen franquista. Un régimen para el cual la vida humana está por debajo del sistema de valores y/o religioso de la cúpula política o de todo aquello que ésta pretende lograr. Es en este momento cuando Muñiz ensambla un nuevo eslabón en la cadena de esa leyenda negra que refrenda a través de su obra: la dictadura de Franco. En las últimas páginas, la denuncia de la hipocresía de aquellos que se refugian en la religión para llevar a cabo las más terribles injusticias es una denuncia de la religión malentendida en general y, puede considerarse también una alusión a la Cruzada en particular y a todas las atrocidades cometidas por ella en nombre de Dios.

DON CARLOS.- Pienso que mi perdón no os servirá cuando hayáis de dar cuentas al Rey de los Reyes... Él os castigará... Él sabe que en su nombre cometéis las mayores vilezas y que a su amparo desatáis vuestro odio y en su nombre aniquiláis la vida... Os perdono a todos porque sé que Él no puede perdonaros si es de veras la Suma Justicia... Os perdono porque ya me es igual. Ante la muerte tú y el trono y la guerra de Flandes y mi padre y sus santas reliquias dais una risa tremenda... Me pregunto por qué los moribundos, que sentirán los mismos deseos de reír que yo siento, no ríen, como tampoco ríe el desdichado príncipe de España... [...] No me extraña que el Señor, indignado con la vileza humana, enviase el Diluvio... Lo que me pregunto últimamente, sin lograr responderme, es... (jadea más intensamente) por qué... por qué no... envía... otro... di... diluvio a la tierra y aniquila juntos, por igual, a mahometanos... (respira hondo y sigue jadeando ahora más intensamente.) calvinistas... lutera... nos... y ca... tólicos...

Frente a la leyenda azul o la completa asunción de la leyenda negra, encontramos posturas intermedias, como la del diplomático e historiador Salvador de Madariaga, miembro del Gobierno Radical de Lerroux pero tremendamente contestatario con el régimen franquista, que criticó duramente desde el exilio. En su faceta como ensayista, Madariaga se había ocupado de figuras míticas de la Historia de España. Suyos son títulos como Vida del muy magnífico señor don Cristóbal Colón (1940), Hernán Cortés (1941), Carlos V (1951) o la polémica biografía del libertador venezolano Bolivar (1951). De 1945 data su obra dramática en verso Don Carlos, donde ofrece una especie de contrapartida a la obra de Schiller, incidiendo más en el tema del afán por medrar del príncipe - primero en Malta y, más tarde en Flandes- que en

${ }^{33}$ ib., p. 525. 
el enfrentamiento directo con su padre. Tanto es así, que Felipe II aparece como personaje presente sólo en un par de escenas de los actos III y IV -aunque su importancia como carácter latente es manifiesta a lo largo de toda la obra- y no se le relaciona de forma directa con la muerte de don Carlos con quien se muestra comprensivo durante su agonía. El Infante es en la de Madariaga un hombre muy determinado por sus características físicas, movido siempre más que por el marcado odio hacia su padre -en el que persistirá hasta su último aliento-, por su afán de progresar en la Corte como su tío don Juan de Austria o su primo Alejandro de Farnesio -más apuestos y mejor valorados por el Rey que él- así como su devoción por su madrastra Isabel de Valois. Sin embargo, no existe en la pieza "demonización" de ningún personaje ni partidismo alguno, tanto es así, que don Carlos, en brazos de Isabel y en el momento postrero, justo antes de morir, declara su amor por su padre, renegando así del odio que había sido el motor de su vida. El de Madariaga, es un drama sin más pretensión que la de abordar un episodio del pasado de una manera más ecuánime que sus predecesores, esto es, limando la imagen heroica del Infante que proponía Schiller, ahondando en su faceta egoísta -puesto que lucha en pro de un beneficio personal más que el de los flamencos-, recalcando su carácter pulsional y, a veces, infantil así como desmintiendo el tratamiento despótico de Felipe II a su vástago. Sobre la España de entonces, resulta elocuente esta intervención de Isabel de Valois: «Porque estos españoles, / domadores de tierras y océanos, / de lunas y de soles, / santos o monstruos son, héroes o enanos, / más o menos que hombres, / nunca humanos. / Y entre gentes sublimes, nobles, fatuas / austeras o grotescas, tú [Ruy Gómez], tan bueno / pasas libre y sereno / como un hombre entre imágenes y estatuas» ${ }^{34}$. Por tanto, en Don Carlos, podríamos hablar de una oposición o revisionismo comedido y razonado a la leyenda negra, merced a su final donde el odio se considera una oquedad que lastra a los personajes y que puede llegar a superarse quizá una metáfora sobre las dos Españas-. A partir de su lectura, se intuye la influencia que supuso esta Don Carlos para la Tragicomedia de Muñiz puesto que el dramatis es parejo así como el tratamiento de la figura protagónica.

Otra interesantísima reflexión a partir de este episodio histórico, ya en el siglo XXI, llegó de la mano de Calixto Bieito y Marc Rosich en su dramaturgia del Don Carlos de Schiller estrenada en el Teatro Valle-Inclán en 2009. En este espectáculo, como sucedía en la obra del romántico alemán, la anécdota queda esencializada en el conflicto entre padre e hijo o, dicho de otro modo, en el choque entre las fuerzas represoras del individuo y las ansias de libertad y renovación de éste. A partir de un pretendido enfoque surrealista, la escenografía presentaba una España simbólica cifrada en el huerto de Felipe II -que él mismo cuidó hasta su muerte y donde cultivaba todo lo que consumía-. Esta España gobernada por el Rey Católico rechazaba los aires aperturistas del Marqués de Poza y silenciaba sistemáticamente el amor

\footnotetext{
${ }^{34}$ S. de Madariaga (1983), p. 151.
} 
entre don Carlos e Isabel. Sin embargo y, pese a partir de una visión más "universal", el montaje también echó mano de los tópicos de la leyenda negra para reflejar, con la estética más burdamente folklórica de los años sesenta -muy asociada al franquismo- una España acartonada, rendida ante la superstición, que sueña como declararía el propio Rosich con «realezas del pasado y miserias del presente ${ }^{35}$. Desde el punto de vista escenográfico, el régimen del General Franco sería, como ya ocurría en Muñiz, un nuevo eslabón de esa leyenda negra. Afirmaba Rosich: «Schiller, en esta pieza de paisaje español sobre temas alemanes, ficcionalizó una imagen determinada, incluso deformada, del imperio de Felipe II, ahondando en su leyenda negra. Nuestro trabajo se ha dirigido a matizar, subrayar, soslayar, aderezar con nuestro comentario escénico, los ecos de la obra que todavía pueden resonar en la historia reciente de nuestro país» ${ }^{36}$.

Como hemos podido, advertir, independientemente de que los hechos dramatizados fuesen o no estrictamente verídicos -labor que compete exclusivamente al historiador y que no podemos ni debemos exigir a una obra de ficción-, resulta harto interesante cómo cada una de las piezas se sirve de los anales, interpretándolos a partir de unos objetivos concretos que sobrepasan lo meramente teatral. En el caso de Tragicomedia del serenísimo príncipe Don Carlos y, como es común a los dramaturgos de la generación realista y a su gran mentor, Buero Vallejo, Muñiz utiliza la historia a la manera de catalizador para su propio contexto sociopolítico. A través de la doble lectura que ofrece el género -muy en especial a partir de Brecht-, el pasado es capaz de ser un exégeta del presente, por lo que se establecen claramente dos niveles de lectura: el meramente historicista y aquél interpretable como parábola del presente. Al hablar de Pemán -estilística e ideológicamente opuesto a Muñiz-, podríamos aludir también a este doble mecanismo aunque mucho más minimizado. Es evidente que en Felipe II, asistimos a una divinización del monarca en base a una intención ejemplarizante del pasado con respecto del presente, así como a una revalorización del personaje histórico de cara a la génesis de una mitología que "justificase" de algún modo la Dictadura ${ }^{37}$. Sin embargo, este mecanismo no es de ida y vuelta y hay una perspectiva más cerrada, deudora del drama histórico al uso de la escuela de Marquina o Madariaga. Digamos que, mientras que Muñiz abre un diálogo con su contemporaneidad y espera una respuesta y una toma de conciencia por parte del espectador -que ha de ser parte activa en la construcción

\footnotetext{
${ }^{35}$ F. V. Schiller (2009), p. 11.

${ }^{36}$ ib., p. 11.

${ }^{37}$ La divinización de Felipe II corría pareja a la que muchos correligionarios del Régimen llevaron a cabo con la figura de Franco. Sin ir más lejos, el propio José María Pemán, declaraba: «Sus palabras son casi hechos, sus gestos son casi acciones, ¿cabe elocuencia más alta y más perfecta? Como que ésta es la fórmula misma de la elocuencia de Dios, cuyas palabras, según los teólogos, obran lo mismo que dicen».
} 
completa del drama-, en Pemán el mensaje es doctrinal y magistral, por lo que no requiere una réplica del público sino una asunción de los postulados expuestos.

A través de las lecturas, se hace patente la fluctuación de la consideración de la leyenda negra y la existencia de los dos bandos que señalaba Julián Marías ${ }^{38}$ en el capítulo dedicado al tema de su ensayo España inteligible: los «contagiados»-que viven en un estado de depresión histórica-y los «indignados» -que rechazan totalmente el antihispanismo y todo lo que pudiera haber de justificado en él- como afirmación o rechazo del sistema político de su tiempo. Una vez más se demuestra que, más que los propios hechos, es el arte y, más en concreto, la literatura, quien es capaz de escribir la historia de un país al calar en el imaginario colectivo más que cualquier otra manifestación cultural. Teniendo esto en cuenta, quizá sería conveniente que, en la actualidad, nuevos dramaturgos, exentos ya de condicionamientos ideológicos extremos, pudiesen formar parte del bando de los «libres», esto es, de aquellos que permanecen abiertos a la verdad y están dispuestos a escudriñar la incertidumbre del claroscuro. Sin duda, siempre es ésta la apuesta más compleja y arriesgada pero también la más teatral.

\section{OBRAS CITADAS}

ESPAÑOL BOUCHÉ, Luis: Leyendas negras. Vida y obra de Julián Juderías, Salamanca, Junta de Castilla y León, 2007.

: "Los orígenes de la expresión «leyenda negra»" en Asturias Digital. Periódico liberal de opinión y noticias, 12-11-2007. [Disponible en

$<\mathrm{http}$ ://www.asturiasliberal.org/colaboraciones/piensa_en_liberal/los_origenes_ de_la_expresion_leyenda_ne.php>. Consultado el 15-3-2013].

FERNÁNDEZ ÁlVAREZ, Manuel: Felipe II y su tiempo, Madrid, Espasa, 2006.

IGLESIAS, Carmen: No siempre lo peor es cierto, Madrid, Galaxia Gutemberg, 2008.

JUDERÍAS, Julián: La leyenda negra. Estudios acerca de España en el extranjero, Salamanca, Junta de Castilla y León, 2003.

LABORDA, Ángel: "Una visión del príncipe don Carlos", Madrid, $A B C$, 11-11-1980.

LÓPEZ SANCHO, Lorenzo: "Historia en su versión atroz: Tragicomedia del serenísimo príncipe Don Carlos", Madrid, ABC, 15-11-1980, p. 53.

MADARIAGA, Salvador de: Don Carlos en Teatro en prosa y verso, Madrid, Espasa Calpe, 1983.

MARÍAS, Julián: España inteligible: razón histórica de las Españas, Madrid, Alianza, 1985.

Molina MARTíneZ, Miguel: "La Leyenda Negra revisitada: la polémica continúa", Revista Hispanoamericana. Revista Digital de la Real Academia Hispano Ame-

${ }^{38}$ J. Marías (1985), p. 199-211. 
ricana de Ciencias, Artes y Letras, 2, 2012. [Disponible en: $<$ http://revista.raha.es/>. Consultado el 25-03-2013].

MuÑIZ, Carlos: Tragicomedia del serenísimo príncipe don Carlos en Teatro escogido, Madrid, Asociación de Autores de Teatro, 2005.

PARKER, Geoffrey: Felipe II. La biografia definitiva, Madrid, Planeta, 2010.

PemÁn, José María: Felipe II. Las soledades del rey, Madrid, Aguilar, 1958.

Peral VegA, Emilio: "De reyes destronados. La figura del rey en el teatro clásico durante la Segunda República" en García Lorenzo, Luciano (ed.) El teatro clásico español a través de sus monarcas, Madrid, Fundamentos, 2006, pp. 351-378.

SCHILLER, Friedrich von: Don Carlos, versión de Calixto Bieito y Marc Rosich, Madrid, Centro Dramático Nacional, 2010.

: (2012): Don Carlos, Infante de España, Madrid, Akal.

TORMO, Elías: "La tragedia del príncipe Don Carlos y la trágica grandeza de Felipe II. Charlas académicas", Boletín de la Real Academia de la Historia, tomo 112 (1943), pp. 161-209.

VILLANUEVA, Jesús: Leyenda negra: una polémica nacionalista en la España del siglo XX, Madrid, Los Libros de la Catarata, 2011. 